\title{
Effect of anesthetic, analgesic and sedative agents on human cell phagocytosis. Review.
}

\author{
Jesús Mosquera e Ivan Pimienta ${ }^{2}$ \\ ${ }^{1}$ Instituto de Investigaciones Clínicas Dr. Américo Neǵrette, Facultad de Medicina, \\ Universidad del Zulia, Maracaibo, Venezuela. \\ ${ }^{2}$ Universidad Regional Autónoma de Los Andes, Uniandes, Ambato, Ecuador.
}

Key words: anesthetics; analgesic; sedatives; phagocytosis.

\begin{abstract}
Along with preoperative stress, anesthetics per se are associated with decreased activity of the immune system. Phagocytosis is an important process where particles, such as dead cells and bacteria, are eliminated from the organism. This process is complex and involves cell chemotaxis, tissue infiltration, several coordinated cellular events and the production of reactive oxygen and nitrogen species (ROS). Therefore, the aim of this review was to report the effects of anesthetic, analgesic and sedative agents on human cell phagocytosis. This review suggests that human phagocytosis processes are affected by main anesthetic, analgesic and sedatives agents that result in decreased chemotaxis, phagocytosis and ROS production. These effects may impair the anti-bacterial function of phagocytes. Clinical anesthesiologists should select the anesthetics and the anesthetic methods with careful consideration of the clinical situation and the immune status of patients, concerning long-term mortality, morbidity, and the optimal prognosis.
\end{abstract}

Corresponding author: Jesús Mosquera. Instituto de Investigaciones Clínicas Dr. Américo Negrette, Facultad de Medicina, Universidad del Zulia, Maracaibo, Venezuela. Email: mosquera99ve@yahoo.com 


\title{
Efecto de los agentes anestésicos, analgésicos y sedativos sobre la fagocitosis celular humana.
}

\author{
Invest Clin 2020; 61 (1): 60-72
}

Palabras clave: anestésicos; analgésicos; sedativos; fagocitosis.

Resumen. La anestesia y el estrés preoperatorio están asociados a la depresión del sistema inmunitario. La fagocitosis es un proceso importante destinado a la eliminación de células muerta y microorganismos. Es un proceso complejo que involucra la quimiotaxis celular, la infiltración tisular leucocitaria y la activación de diversos procesos intracelulares coordinados, que incluyen la producción de especies reactivas de oxígeno y nitrógeno (ERON). Por lo tanto, el propósito de esta revisión fue reportar el efecto de agentes anestésicos, analgésicos y sedativos en la fagocitosis humana. Esta revisión sugiere que los procesos relacionados con la fagocitosis humana son afectados por los principales agentes anestésicos, analgésicos y sedativos, que inducen una disminución de la quimiotaxis, fagocitosis y producción de ERON y la función anti-bacterial de los fagocitos. Los anestesiólogos clínicos deben seleccionar los anestésicos y los métodos de anestesia, considerando la situación clínica y el estado inmunitario de los pacientes en relación a la mortalidad, morbilidad y pronóstico óptimo a largo plazo.

Received: 06-09-2019 Accepted: 23-01-2020

\section{INTRODUCTION}

Anesthetics are a diverse group of drugs used in the management of pain. The administration of anesthetics is necessary to provide inhibition of individual pain pathways (local anesthesia) or to render a patient unconscious so that surgical procedures can be carried out (general anesthesia) (1). Phagocytosis is a process where cells surround and engulf particles such as dead cells and bacteria. This is important both, for singlecell organisms (to acquire nutrients) and as part of the immune system (to destroy foreign invaders). This process is complex and involves several coordinated events such as membrane remodeling, receptor motion, cytoskeleton reorganization and intracellular signaling (2). Before phagocytosis is accomplished, the phagocyte and the particle must adhere to each other. The mechanisms involved in this attachment depend on the chemical nature of the particle's surface. The capacity of phagocytes to engulf microorganisms plays an important role in the immune defense (3). However, drugs that might impair their engulfing capacity can induce immunosuppression (4). Patients that undergo surgical interventions are exposed to anesthetic and analgesic drugs during the procedure that, together with perioperative stress, may impair phagocytes function and expose to infections $(4,5)$. Therefore, we con ducted this review to obtain information regarding the effects of relevant anesthetic, analgesic and sedative agents on human cell phagocytosis. Multiple literature searches were performed from1973 through 2019 using online databases from PubMed, Scielo and Bireme.

Vol. 61(1): 60 - 72, 2020 


\section{EFFECTS OF DRUGS ON HUMAN PHAGOCYTOSIS}

\section{Inhaled general anesthetics \\ Isoflurane}

With respect to this inhaled anesthetic agent, studies had shown controversial results. It has been reported to have no effect on phagocytosis (opsonized E. Coli) of human neutrophils in patients undergoing elective interventional embolization of cerebral arterio-venous malformations (6). Isofluorane did not alter phagocytosis of latex by human monocytes (7). In vitro exposure to isoflurane for $90 \mathrm{~min}$ does not significantly alter the phagocytic capacity (Escherichia coli) of neutrophils from women during pregnancy (8). Isoflurane promoted phagocytosis (efferocytosis) of apoptotic cells by macrophages, via upregulation of Mer surface expression, through AMPK-mediated blockade of ADAM17 trafficking to the cell membrane (9). In a gas concentration assay, chemiluminescence, superoxide production, and hydrogen peroxide production induced by opsonized zymosan as a phagocytic stimulus were not altered by isoflurane (10). However, altered phagocytic function due to this drug has been reported. Decreased phagocytosis (opsonized and unopsonized Listeria monocytogenes) was reported using this drug in alveolar macrophages from bronchoalveolar lavage obtained during orthopedic surgery (11). Isoflurane exposure also decreased human neutrophil phagocytosis (12).

\section{Halothane}

In general halothane induces alteration of phagocytic function of phagocytes. Anesthesia with halothane induced decreased chemotactic, phagocytic and bactericidal activity in patients with pathological injuryeffected changes or due to varicose veins of extremities (13). Anesthesia with halothane caused a dose-related depressant effect on human neutrophil phagocytic index and a nitroblue-tetrazolium reduction test in patients undergoing gynecological surgery (14). Anesthesia with halothane induced de- creased release of oxygen-free radicals during the phagocytosis of zymosan A by human neutrophils (15). In an assay gas concentration, chemiluminescence, superoxide production, and hydrogen peroxide production induced by opsonized zymosan as a phagocytic stimulus, were diminished by halothane (10). However, in other studies halothane failed to alter the phagocytic function. In this regard, halothane did not inhibit human neutrophil phagocytosis, degranulation and the enhanced non-mitochondrial respiration associated with phagocytosis function in vitro (16).

\section{Sevoflurane}

This drug does not alter neither phagocytosis of human polymorphonuclear leucocytes in bronchoalveolar lavage from patients under anesthesia (17) or phagocytosis (E Coli), and oxidative burst of circulating granulocytes and monocytes (18).

\section{Desflurane}

This drug does not alter phagocytosis of human polymorphonuclear leucocytes in broncoalveolar lavage from patients under anesthesia (17).

\section{Enflurane}

Enflurane causes significantly greater depression of human neutrophil phagocytic index and nitroblue tetrazolium reduction test in patients undergoing gynecological surgery (14) and induces decreased release of oxygen-free radicals during the phagocytosis of zymosan A and Bordetella pertussis by human neutrophils $(15,19)$.

\section{Nitrous oxide}

Nitrous oxide decreases neutrophil antibacterial capacity in vitro. Exposure of human whole blood to nitrous oxide decreased the percentage of neutrophils showing phagocytosis, and the amount of ingested bacteria (20). Nitrous oxide also decreases release of oxygen-free radicals during serumopsonized zymosan and Bordetella pertussis phagocytosis by human neutrophils (19).

Xenon

Phagocytosis (E Coli) and oxidative burst of granulocytes were reduced with xe- 
non anesthesia, whereas monocytes were not affected (18). However, xenon preserved neutrophil and monocyte antibacterial capacity in vitro. Exposure of human whole blood to xenon increased the percentage of neutrophils showing phagocytosis, and the amount of ingested bacteria. Respiratory burst activity in neutrophils and monocytes was not affected by xenon (20).

Methoxyflurane

No information was found.

\section{Intravenous general anesthetics Propofol}

The intravenous anesthetic agent propofol is used to induce and maintain anesthesia during surgical or other invasive procedures and to sedate critically ill patients $(21,22)$. Previous studies have shown that this drug has controversial effects regarding the phagocytic functions. This anesthetic drug acts via stimulation of the $\beta_{2}$-subunit of the $\mathrm{GABA}_{\mathrm{A}}$ receptors inducing impairment of chemotaxis and phagocytosis (microspheres) of circulating human monocytes and macrophages (23-25). Propofol inhibits phagocytosis (latex beads) via the $\mathrm{GABA}_{\mathrm{A}}$ receptor and dysregulation of p130cas phosphorylation in macrophages from patients undergoing general anesthesia (26). In vitro studies have shown that propofol inhibits human neutrophil chemotaxis, phagocytosis and reactive oxygen species (ROS) $\left(\mathrm{O}_{2}^{-}\right.$, $\left.\mathrm{H}_{2} \mathrm{O}_{2}, \mathrm{OH}\right)$ production, in a dose-dependent manner (27). In vitro studies have shown that propofol diminishes human neutrophil and monocyte phagocytosis (E Coli) and oxidative burst even in clinically concentrations (28). In vitro studies showed that propofol inhibited phagocytosis and killing of Staphylococcus aureus as well as Escherichia Coli (29). However, other studies showed that propofol failed to alter phagocytosis and associated processes. In this regard, this drug did not alter the phagocytosis of Staphylococcus aureus by human monocytes (30) or phagocytosis of Candida albicans by human neutrophils (31). Propofol does not alter phagocytosis of human polymorphonuclear leucocytes in broncoalveolar lavage from patients under anesthesia (17) or from patients undergoing coronary artery bypass grafting (32). No alteration of human neutrophil phagocytosis (opsonized E. Coli) using propofol, in patients undergoing elective interventional embolization of cerebral arterio-venous malformations, has been reported (6). No alteration on phagocytosis (opsonized and unopsonized Listeria monocytogenes) was reported using this drug in alveolar macrophages from bronchoalveolar lavage obtained during orthopedic surgery (11). Propofol at the higher concentration failed to reduce both respiratory burst and phagocytosis (Staphylococcus aureus) of human neutrophils (33). Propofol exhibited no significant effects on human neutrophil oxidative burst and phagocytosis (E. Coli) in patients with severe brain injury requiring long-term sedation (34). Propofol, at clinically relevant concentrations, reduces chemotaxis but fail to reduce phagocytosis of human neutrophils (35). In addition, propofol stimulated human microglial phagocytosis in vitro (36).

\section{Ketamine}

Controversial results regarding the effect of ketamine have been reported. Clinically relevant concentrations of ketamine can suppress macrophage function of phagocytosis, its oxidative ability, and inflammatory cytokine production, possibly via reduction of the mitochondrial membrane potential (37). Ketamine significantly inhibited both phagocytosis (Staphylococcus aureus and Escherichia coli) and bactericidal activity by human neutrophils (38). In vitro studies have shown that ketamine diminishes human monocyte phagocytosis (E Coli) at high concentrations (28). However, other studies showed no effect on the phagocytic function of phagocytes. In his regard, ketamine did not adversely affect phagocytic function of human neutrophils at relevant therapeutic concentrations (39). No depressed phagocytosis and ROS production of human neu-

Vol. 61(1): 60 - 72, 2020 
trophil was observed in vitro by the use of ketamine at clinically concentrations (40). Ketamine at a higher concentration fail to reduce both respiratory burst and phagocytosis (Staphylococcus aureus) of human neutrophils (33).

\section{Etomidate}

In vitro studies have shown that this drug significantly inhibited both phagocytosis (Staphylococcus aureus and Escherichia coli) and bactericidal activity (41).

\section{Thiopental}

Thiopental at clinically relevant concentrations reduced both chemotaxis and phagocytosis of human neutrophils (35) and at the higher concentration reduced both respiratory burst and phagocytosis (Staphylococcus aureus) of human neutrophils (33). In vitro studies showed that thiopental decreased human neutrophil chemiluminescence (respiratory burst) and phagocytosis (Staphylococcus aureus and Escherichia coli) at clinical drug concentrations in a dose-dependent fashion (42). According to this, Nishima et al (40) reported that thiopental was capable of decreasing at clinically relevant concentrations chemotaxis, phagocytosis, and reactive oxygen species (ROS) $\left(\mathrm{O}_{2}-, \mathrm{H}_{2} \mathrm{O}_{2}, \mathrm{OH}\right)$ production of human neutrophils. The impairment of phagocytic function (microspheres) has also been reported in human monocytes, mediated via stimulation of GABA receptors by thiopental (25). In addition, thiopental can also depress the phagocytosis of Staphylococcus aureus by human monocytes (43). In vitro studies have shown that thiopental diminishes human neutrophil and monocyte oxidative burst induced after phagocytosis (Staphylococcus aureus and Escherichia coli) at high concentrations $(28,38)$.

\section{Sedatives and tranquilizers \\ Dexmedetomidine}

Dexmedetomidine is a highly-selective $\alpha_{2}$-adrenergic receptor agonist used for sedation of critically ill patients in an intensive care setting and as adjuncts to anesthesia.
Previous studies have shown that clinical doses of this drug has no effects on chemotaxis, phagocytosis or superoxide anion $\left(\mathrm{O}_{2}-\right)$ production of human neutrophils, suggesting that this drug may be useful in patients with infection, sepsis, or systemic inflammation (5). According to this, in vitro studies have shown that clinically relevant concentrations of dexmedetomidine do not affect chemotaxis, phagocytosis, or superoxide production by human neutrophils (44). However, decreased human neutrophil phagocytosis of E. Coli, associated with suppressed respiratory burst, nitric oxide (NO) production, and induced nitric oxide synthase (iNOS) activity induced by dexmedetomidine have been reported (45).

\section{Clonidine}

This is a $\alpha_{2}$-adrenergic receptor agonist also used as adjuncts to anesthesia. Chemotaxis, phagocytosis and further production of superoxide anion of human neutrophils, are not altered by the used of this drug (5) and in vitro studies had shown that clinically relevant concentrations of clonidine do not affect chemotaxis, phagocytosis, or superoxide production by human neutrophils (44). However, this drug inhibits phagocytosis of cultured human trabecular meshwork cells (isolated from the juxtacanalicular and corneoscleral regions of the human eye) (46).

Xylasine

This alpha2-agonist had no effects on chemotaxis, phagocytosis, or superoxide anion $\left(\mathrm{O}_{2}-\right)$ production of human neutrophils; the lack of effect of this drug has also been reported by in vitro studies $(5,44)$.

\section{Barbiturates}

Methohexital

It has been reported that this barbiturate is capable of decreasing the phagocytosis of viable $S$. aureus by human monocytes (43). In vitro studies showed that methohexital inhibited granulocyte recruitment and phagocytosis activity ( $S$. aureus) in a dose-dependent manner (47). However, other studies show that it failed to alter 
the phagocitic function. In this regard, this drug did not influence human neutrophil chemiluminescence (respiratory burst) in a dose-dependent fashion (42). Methohexital exhibited no significant effects on human neutrophil oxidative burst and phagocytosis (E. Coli) in patients with severe brain injury requiring long-term sedation (34).

\section{Pentobarbital}

This drug did not influence human neutrophil chemiluminescence (respiratory burst) in a dose-dependent fashion (42).

\section{Phenobarbital}

In vitro studies showed that phenobarbital decreased human neutrophil chemiluminescence (respiratory burst) in a dosedependent fashion (42).

\section{Thiamylal}

Subclinical doses of thiamylal caused enhancement of the human phagocytic activity of neutrophils, however, super-clinical doses of thiamylal inhibited phagocytic activity of these cells (39).

Amobarbital

No information was found.

\section{Benzodiazepines}

\section{Diasepam}

This benzodiazepine did not alter phagocytic function (microspheres) in human monocytes (25). In addition this drug in concentration-dependently doses increased chemotaxis and phagocytosis in isolated human neutrophils by $\mathrm{Ca} 2+$-independent mechanisms (48). However, diazepam is inhibitory in vitro for the phagocytic functions being its action mediated via specific receptors on immunocompetent cells (49).

\section{Midazolam}

At clinically concentrations this intravenous anesthetic depress human neutrophil phagocytosis and further production of ROS (40). In vitro studies have shown that midazolam diminishes human neutrophil oxidative burst after phagocytosis (E Coli) at high concentrations (28), but failed to reduce both respiratory burst and phagocytosis of S. aureus (33).

\section{Flunitrazepam}

In vitro studies showed that this drug significantly inhibited both phagocytosis (Staphylococcus aureus and Escherichia coli) and bactericidal activity (41).

Alprazolam

Alprazolam increases human neutrophil phagocytosis of bacteria and further killing and monocyte phagocytosis without modifying antibacterial activity values (50).

\section{Lorazepam}

No information was found

\section{Phenothiazines}

Promethasine

In general this drug alters the production of ROS, necessary to destroy ingested bacteria. Promethazine predominantly affected the ability of macrophages to produce $\mathrm{O}_{2}$ - during phagocytosis (51). Promethazine also affected the ability of human neutrophils to produce $\mathrm{O}_{2}$ - and hexose monophosphate shunt activity during phagocytosis (opsonized zymosan) $(52,53)$.

\section{Chlorpromazine}

Chlorpromazine increases killing activity against $S$. aureus phagocytosed by human monocyte-derived macrophages (54).

Acepromasine

No information was found.

\section{Opioids}

Fentanyl

Fentanyl failed to inhibit receptor expression, phagocytosis and reactive oxygen production by monocytes in clinically relevant as well as supraclinical concentrations (55). Intravenous injection of fentanyl did not alter human neutrophil phagocytic function and superoxide anion generation (56, $57)$. In addition, in vitro studies showed that fentanyl did not influence phagocytosis as well as bactericidal activity in human neutrophils (41). However, high-dose fentanyl anesthesia in patients undergoing coronary bypass surgery showed decreased phagocytosis of zymosan, $S$. aureus and E. coli by human granulocytes (58). 


\section{Alfentanil}

In vitro studies showed that alfentanyl did not influence phagocytosis as well as bactericidal activity in human neutrophils (41). However, this drug alters phagocytosis of latex by human monocytes (7).

Remifentanil

No information was found.

Sufentanil

No information was found.

\section{Butyrophenones}

Droperidol

This drug is used as a sedation adjunct to general anesthesia. In vitro studies showed that droperidol caused a significant inhibition of phagocytosis as well as bactericidal activity in human neutrophils (41).

\section{Local Anesthetics}

\section{Bupivacaine}

In vitro studies showed that bupivacaine alters phagocytic functions. In this regard, this drug inhibited priming of LPS on human neutrophils (59). Bupivacaine in a time-dependent manner diminished phagocytosis, bacterial uptake, oxidative burst and CD11b expression by human neutrophils (43). Bupivacaine impairs surface receptor expression Fe gamma receptor III (CD16), complement receptor 1 (CD35) and complement receptor 3 (CD11b) and may thereby contribute to reduced phagocytic activity and oxidative burst (60). Other studies report different effect of this drug. In vitro studies showed that bupivacaine did not alter the chemotaxis, phagocytosis and oxidative burst of human neutrophils at clinically doses $(61,62)$.

\section{Lidocaine}

Lidocaine inhibited adhesion, chemotaxis, phagocytosis, and the production of superoxide anion and hydrogen peroxide by neutrophils and macrophages $(62,63)$. Lidocaine also diminished phagocytosis, bacterial uptake, oxidative burst and CD11b expression in human neutrophils, in a time-dependent manner $(30,61)$. In vitro studies showed that lidocaine inhibited priming of LPS on human neutrophils (59).

\section{Procaine}

Procaine inhibits adhesion, chemotaxis, phagocytosis, and the production of superoxide anion and hydrogen peroxide by neutrophils and macrophages (63). Procaine also inhibited the phagocytosis of latex particles by normal monocytes (64). In vitro studies showed that procaine inhibited priming of LPS on human neutrophils (59).

\section{Tetracaine}

In vitro studies showed that tetracaine inhibited priming of LPS on human neutrophils (59), and inhibited adhesion, chemotaxis, phagocytosis, and the production of superoxide anion and hydrogen peroxide by neutrophils and macrophages (63).

\section{Mepivacaine}

Mepivacaine inhibits adhesion, chemotaxis, phagocytosis, and the production of superoxide anion and hydrogen peroxide by neutrophils and macrophages (63).

\section{CONCLUSIONS}

The accumulated evidence described above suggests that human phagocytosis processes seem to be more sensitive to the main anesthetic, analgesic and sedatives agents, which results in decreased chemotaxis, phagocytosis and ROS production and leads to impairment of the anti-bacterial function by phagocytes (Table I). However, different results between those obtained from patients and those obtained from in vitro experiments, have been reported. Probably direct information obtained from patients before and after surgery, represents a closer view of real effect of anesthetic drugs. In addition, the attenuation of the preoperative stress responses, by a combination of sedative drugs with general anesthesia, can protect surgical patients from further alteration of phagocytosis processes during the preoperative period. This is very important in patients with risk of microorganism infec- 
tions. Other situation to be analyzed is the combination of different drugs used during anesthesia and the final effect of that combination and the preparation of drugs used for anesthesia (65). The negative consequences associated with preoperative immunosuppression, such as an increased risk of postoperative infection, could be decreased by the optimal selection of anesthetics and anesthetic techniques. Concerning the stress response induced by anesthesia, intravenous anesthesia may be superior to inhalation anesthesia in reducing hypothalamic-pituitary adrenal axis activation (66). In the future, anesthetic protocols may be chosen not only for their anesthetic and analgesic effects, but also for their immunomodulatory effects, considering the underlying conditions for which the patients need to be anesthetized (4, 67-69).

Neuraxial anesthesia provide several advantages over other anesthetic agents, including decreased risk of infection through attenuation of the stress response and preservation of immune function (70-73). Despite these benefits, patients with altered immune status are often not considered candidates for neuraxial techniques because of the risk of infection (74).

Despite these documented effects on human phagocytosis, the clinical importance of anesthesia-mediated changes in perioperative immunosupression remains uncertain. Currently, there are no clinical studies evaluating the influence of choice of anesthesia and analgesia on the outcome after oncologic surgery or in immunocompromised patients.

In general, the drugs used during anesthesia induce suppressed phagocytosis processes; therefore, the anesthetic protocols may be chosen not only for their anesthetic and analgesic effects, but also for their immunomodulatory effects. There is evidence suggesting that the choice of anesthetic is important when considering the underlying condition of the particular patient.

TABLE I

EFFECT OF ANESTHETIC, ANALGESIC AND SEDATIVE AGENTS ON HUMAN PHAGOCYTOSIS PROCESSES

\begin{tabular}{|c|c|c|}
\hline Agents & $\begin{array}{l}\text { Effect on } \\
\text { phagocytosis } \\
\text { processes }\end{array}$ & References \\
\hline Isoflurane & $\downarrow /$ ne & $\begin{array}{l}\text { Lieners et al., } 1989 \text { (10); Carrera et al., } 1993 \text { (7); Clark et al., } \\
1993 \text { (8); Kotani et al., } 1998 \text { (11); Heine et al., } 2000 \text { (6); Du et al., } \\
2017 \text { (9); Koutsogiannaki et al., } 2019 \text { (12) }\end{array}$ \\
\hline Halothane & $\downarrow /$ ne & $\begin{array}{l}\text { Nunn et al., } 1979 \text { (16); Barth et al., } 1987 \text { (15); Lieners et al., } 1989 \\
\text { (10); Khan et al., } 1995 \text { (14); Ciepichał and Kübler, } 1998 \text { (13) }\end{array}$ \\
\hline Sevoflurane & ne & Erol et al., 2009 (17); Fahlenkamp et al., 2014 (18) \\
\hline Desflurane & ne & Erol et al., 2009 (17) \\
\hline Enflurane & $\downarrow$ & $\begin{array}{l}\text { Perttilä et al., } 1986 \text { (19); Barth et al., } 1987 \text { (15); Khan et al., } 1995 \\
\text { (14) }\end{array}$ \\
\hline Nitrous oxide & $\downarrow$ & Perttilä et al., 1986 (19); De Rossi et al., 2002 (20) \\
\hline Xenon & $\downarrow /$ ne & De Rossi et al., 2002 (20); Fahlenkamp et al., 2014 (18) \\
\hline Propofol & $\downarrow /$ ne & $\begin{array}{l}\text { Ince et al., } 1988 \text { (24); Krumholz et al., } 1994 \text { (29); Skoutelis et al., } \\
1994 \text { (35); Davinson et al., } 1995 \text { (33); Mikawa et al., } 1998 \text { (27); } \\
\text { Heller et al., } 1998 \text { (28); Kotani et al., } 1998 \text { (11); Heine et al., } 2000 \\
\text { (6); Bali and Akabas, 2004 (23); Coreoran et al., } 2006 \text { (32); Huet- } \\
\text { temann et al., } 2006 \text { (34); Ploppa et al., } 2008 \text { (30); Shiratsuchi et } \\
\text { al ., } 2009 \text { (26); Erol et al., } 2009 \text { (17); Wheeler et al., } 2011 \text { (25); Yu } \\
\text { et al. } 2011 \text { (36); Bravo et al., } 2019 \text { (31) }\end{array}$ \\
\hline
\end{tabular}

Vol. 61(1): 60 - 72, 2020 
TABLE I. CONTINUACIÓN

\begin{tabular}{|c|c|c|}
\hline Agents & $\begin{array}{l}\text { Effect on } \\
\text { phagocytosis } \\
\text { processes }\end{array}$ & References \\
\hline Ketamine & $\downarrow /$ ne & $\begin{array}{l}\text { Krumholz et al., } 1995 \text { (38, 41); Toyota et al., } 1995 \text { (39); Davinson } \\
\text { et al., } 1995 \text { (33); Heller et al., } 1998 \text { (28); Nishina et al., } 1998 \text { (40); } \\
\text { Chang et al., } 2005 \text { (37) }\end{array}$ \\
\hline Etomidate & $\downarrow$ & Krumholz et al. $1995(38,41)$ \\
\hline Thiopental & $\downarrow$ & $\begin{array}{l}\text { Salo and Perttilä et al., } 1989 \text { (19); Skoutelis et al., } 1994 \text { (35); } \\
\text { Weiss et al., 1994 (42); Davinson et al., } 1995 \text { (33); Krumholz et al. } \\
1995 \text { (38, 41); Heller et al., } 1998 \text { (28); Nishina et al., } 1998 \text { (40); } \\
\text { Ploppa et al., } 2008 \text { (43); Wheeler et al., } 2011 \text { (25) }\end{array}$ \\
\hline Dexmedetomidine & $\downarrow /$ ne & $\begin{array}{l}\text { Nishima et al., } 1999 \text { (44); Anderson et al., } 2014 \text { (5); Chen et al., } \\
2016 \text { (45) }\end{array}$ \\
\hline Clonidine & $\downarrow /$ ne & $\begin{array}{l}\text { Wang et al., } 1994 \text { (46); Nishima et al., } 1999 \text { (44); Anderson et al., } \\
2014 \text { (5) }\end{array}$ \\
\hline Xylazine & ne & Nishima et al., 1999 (44); Anderson et al., 2014 (5) \\
\hline Methohexital & $\downarrow /$ ne & $\begin{array}{l}\text { Weiss et al., } 1994(42) \text {; Huettemann et al., } 2006 \text { (34); Ploppa et } \\
\text { al., } 2006 \text { (47); Ploppa et al., } 2008(30,43)\end{array}$ \\
\hline Pentobarbital & ne & Weiss et al., 1994 (42) \\
\hline Phenobarbital & $\downarrow$ & Weiss et al., 1994 (42) \\
\hline Thiamylal & $\downarrow$ & Toyota et al., 1995 (39) \\
\hline Diazepam & $\downarrow /$ ne & $\begin{array}{l}\text { Covelli et al., } 1991 \text { (49); Marino et al., } 2001 \text { (48); Wheeler et al., } \\
2011 \text { (25) }\end{array}$ \\
\hline Midazolam & $\downarrow /$ ne & $\begin{array}{l}\text { Davinson et al., } 1995 \text { (33); Heller et al., } 1998 \text { (28); Nishina et al., } \\
1998 \text { (40) }\end{array}$ \\
\hline Flunitrazepam & $\downarrow$ & Krumholz et al., 1995 (41) \\
\hline Alprazolam & $\uparrow$ & Covelli et al., 1993 (49) \\
\hline Promethazine & $\downarrow$ & $\begin{array}{l}\text { DeChatelet et al., } 1973 \text { (53); Trush and Van Dyke, } 1978 \text { (52); Tra- } \\
\text { ykov et al.,1997 (51) }\end{array}$ \\
\hline Chlorpromazine & $\uparrow$ & Ordway et al. 2002 (54) \\
\hline Fentanyl & $\downarrow /$ ne & $\begin{array}{l}\text { Perttilä et al., } 1986 \text { (58); Krumholz et al., } 1995 \text { (41); Welters et al., } \\
2000 \text { (57); Yeager et al., } 2002 \text { (56); Menzebach et al., } 2004 \text { (55) }\end{array}$ \\
\hline Alfentanil & $\downarrow /$ ne & Carrera et al., 1993 (7); Krumholz et al., 1995 (38) \\
\hline Droperidol & $\downarrow$ & Krumholz et al., 1995 (38) \\
\hline Bupivacaine & $\downarrow /$ ne & $\begin{array}{l}\text { Welters et al., } 2001 \text { (60); Mikawa et al., } 2003 \text { (61); Jinnouchi et } \\
\text { al, } 2005 \text { (59); Ploppa et al., } 2008 \text { (30); Kawasaki et al., } 2010 \text { (62) }\end{array}$ \\
\hline Lidocaine & $\downarrow$ & $\begin{array}{l}\text { Mikawa et al., } 2003 \text { (61); Azuma and Ohura, } 2004 \text { (63); Jinnouchi } \\
\text { et al, } 2005 \text { (59); Ploppa et al., } 2008 \text { (30); Kawasaki et al., } 2010 \text { (62) }\end{array}$ \\
\hline Procaine & $\downarrow$ & $\begin{array}{l}\text { Jurjus et al., } 1988 \text { (64); Azuma and Ohura, } 2004 \text { (63); Jinnouchi } \\
\text { et al, } 2005 \text { (59) }\end{array}$ \\
\hline Tetracaine & $\downarrow$ & Azuma and Ohura, 2004 (63); Jinnouchi et al., 2005 (59) \\
\hline Mepivacaine & $\downarrow$ & Azuma and Ohura, 2004 (63) \\
\hline
\end{tabular}

ne: no effect. 


\section{REFERENCES}

1. Miller RD. Miller's Anesthesia. 7th ed. USA: Churchill Livingstone Elsevier; 2010.

2. Richards DM, Endres RG. How cells engulf: a review of theoretical approaches to phagocytosis. Rep Prog Phys 2017; 80: 1-51. doi: 10.1088/1361-6633/aa8730.

3. Friedman H, Newton C, Klein TW. Microbial infections, immunomodulation, and drugs of abuse. Clin Microbiol Rev 2003; 16: 209 219. doi: 10.1128/cmr.16.2.209-219.2003.

4. Kurosawa S, Kato M. Anesthetics, immune cells, and immune responses. J Anesth 2008; 22: 263-277. doi: 10.1007/s00540008-0626-2.

5. Anderson SL, Duke-Novakovski T, Singh B. The immune response to anesthesia: part 2 sedatives, opioids, and injectable anesthetic agents. Vet Anaesth Analg 2014; 41: 553-566. doi: 10.1111/vaa.12191

6. Heine $\mathbf{J}$, Jaeger $\mathrm{K}$, Osthaus $\mathbf{A}$, Weingaertner N, Münte S, Piepenbrock S, Leuwer M. Anaesthesia with propofol decreases FMLPinduced neutrophil respiratory burst but not phagocytosis compared with isoflurane. Br J Anaesth 2000; 85:424-430. https:// doi.org/10.1093/bja/85.3.424

7. Carrera JA, Catalá J, Monedero P, Hidalgo F, Carrascosa F, Arroyo JL. Comparison of the effects of isoflurane and alfentanyl on the mononuclear-phagocytic system. Rev Esp Anestesiol Reanim 1993; 40: 3-8.

8. Clark P, Layon AJ, Duff P. Effect of isoflurane on neutrophil phagocytic function during pregnancy. Infect Dis Obstet Gynecol 1993; 1: 98-103. doi: 10.1155/ S1064744993000237.

9. Du X, Jiang C, Lv Y, Dull RO, Zhao YY, Schwartz DE, Hu G. Isoflurane promotes phagocytosis of apoptotic neutrophils through AMPK-mediated ADAM17/Mer signaling. PLoS One 2017; 12: e0180213. doi: 10.1371/journal.pone.0180213.

10. Lieners C, Redl H, Schlag G, Hammerschmidt DE. Inhibition by halothane, but not by isoflurane, of oxidative response to opsonized zymosan in whole blood. Inflammation 1989; 13: 621-630.

11. Kotani N, Hashimoto H, Sessler DI, Kikuchi A, Suzuki A, Takahashi S, Muraoka M, Matsuki A. Intraoperative modulation of alveolar macrophage function during isoflurane and propofolanesthesia. Anesthesiology 1998; 89: 1125-1132.

12. Koutsogiannaki S, Bernier R, Tazawa K, Yuki K. Volatile Anesthetic Attenuates Phagocyte Function and Worsens Bacterial Loads in Wounds. J Surg Res 2019; 233:323330. doi: 10.1016/j.jss.2018.07.075.

13. Ciepichał $\mathbf{J}$, Kübler A. Effect of general and regional anesthesia on some neutrophil functions. Arch Immunol Ther Exp (Warsz) 1998; 46: 183-192.

14. Khan FA, Kamal RS, Mithani CH, Khurshid M. Effect of general anaesthesia and surgery on neutrophil function. Anaesthesia 1995; 50: 769-775. https://doi. org $/ 10.1111 / j .1365-2044.1995 . t b 06137 . x$

15. Barth J, Petermann W, Entzian P, Wustrow C, Wustrow J, Ohnhaus EE. Modulation of oxygen-free radicals from human leukoeytes during halothane- and enflurane- induced general anesthesia. Acta Anaesthesiol Scand 1987; 31:740-743. https://doi. org/10.1111/j.1399-6576.1987.tb02656.x

16. Nunn JF, Sturrock JE, Jones AJ, O'Moráin C, Segal AW, Coade SB, Dorling J, Walker D. Halothane does not inhibit human neutrophil function in vitro. Br J Anaesth 1979; 51: 1101-1108.

17. Erol A, Reisli R, Reisli I, Kara R, Otelcioglu S. Effects of desflurane, sevoflurane and propofol on phagocytosis and respiratory burst activity of human polymorphonuclear leucocytes in bronchoalveolar lavage. Eur J Anaesthesiol 2009; 26:150-154. doi: 10.1097/EJA.0b013e328319bfeb.

18. Fahlenkamp AV, Coburn M, Rossaint R, Stoppe C, Haase H. Comparison of the effects of xenon and sevoflurane anaesthesia on leucocyte function in surgical patients: a randomized trial. Br J Anaesth 2014; 112: 272-280. doi: 10.1093/bja/aet330.

19. Perttilä J, Lilius EM, Salo M. Effects of anaesthesia and surgery on serum opsonic capacity. Acta Anaesthesiol Scand 1986; 30:173-176. https://doi. org/10.1111/j.1399-6576.1986.tb02391.x

20. De Rossi L, Gott K, Horn N, Hecker K, Hutschenreuter G, Rossaint R. Xenon preserves neutrophil and monocyte function in human whole blood. Can J Anaesth 2002; 49: 942-945. doi: 10.1007/BF03016879.

Vol. 61(1): 60 - 72, 2020 
21. Mackenzie N, Grant IS. Propofol for intravenous sedation. Anaesthesia 1987; 42: 3-6.

22. Wilson E, David A, MacKenzie N, Grant IS. Sedation during spinal anaesthesia: comparison of propofol and midazolam. $\mathrm{Br}$ J Anaesth 1990; 64: 48-52.

23. Bali M, Akabas MH. Defining the propofol binding site location on the GABAA receptor. Mol Pharmacol 2004; 65: 68-76. https://doi.org/10.1093/bja/64.1.48.

24. Ince C, Coremans JM, Ypey DL, Leijh PC, Verveen AA, van Furth R. Phagocytosis by human macrophages is accompanied by changes in ionic channel currents. J Cell Biol 1988; 106: 1873-1878. doi:10.1083/ jcb.106.6.1873.

25. Wheeler DW, Thompson AJ, Corletto F, Reckless J, Loke JCT, Lapaque N, Grant AJ, Mastroeni P, Grainger DJ, Padgett CL, O'Brien JA, Miller NG, Trowsdale J, Lummis SC, Menon DK, Beech JS. Anaesthetic impairment of immune function is mediated via GABAA receptors. PLoS ONE 2011; 6: e17152. doi:10.1371/journal. pone.0017152.

26. Shiratsuchi H, Kouatli Y, Yu GX, Marsh HM, Basson MD. Propofol inhibits pressure-stimulated macrophage phagocytosis via the GABAA receptor and dysregulation of p130cas phosphorylation. Am J Physiol Cell Physiol 2009; 296: C1400-1410. doi: 10.1152/ajpcell.00345.2008.

27. Mikawa K, Akamatsu H, Nishina K, Shiga M, Maekawa N, Obara H, Niwa Y. Propofol inhibits human neutrophil functions. Anesth Analg 1998; 87: 695-700. doi: 10.1213/00000539-199809000-00039.

28. Heller A, Heller S, Blecken S, Urbaschek R, Koch T. Effects of intravenous anesthetics on bacterial elimination in human blood in vitro. Acta Anaesthesiol Scand 1998; 42: 518-526. https://doi. org/10.1111/j.1399-6576.1998.tb05160.x

29. Krumholz W, Endrass J, Hempelmann G. Propofol inhibits phagocytosis and killing of Staphylococcus aureus and Escherichia coli by polymorphonuclear leukocytes in vitro. Can J Anaesth 1994; 41: 446-449. doi:10.1007/BF03009871.

30. Ploppa A, Kiefer RT, Krueger WA, Unertl KE, Durieux ME. Local anesthetics timedependently inhibit staphylococeus aureus phagocytosis, oxidative burst and CD11b expression by human neutrophils. Reg Anesth Pain Med 2008; 33: 297-303. doi: 10.1016/j.rapm.2007.05.012.

31. Bravo J, Zúñiga M, Carrero Y, Mosquera J. Propofol, fentanyl and remifentanil do not impair the phagocytic eapacity to Candida albicans of human peripheral blood polimorphonuclear cells. Rev Chi Anestesiol 2019; 48: 459-462. doi:10.25237/revchilanestv48n05.11.

32. Corcoran TB, Engel A, Sakamoto H, O'Shea A, O'Callaghan-Enright S, Shorten GD. The effects of propofol on neutrophil function, lipid peroxidation and inflammatory response during elective coronary artery bypass grafting in patients with impaired ventricular function. Br J Anaesth 2006; 97:825-831. doi: 10.1093/bja/ ael270.

33. Davidson JA, Boom SJ, Pearsall FJ, Zhang P, Ramsay G. Comparison of the effects of four i.v. anaesthetic agents on polymorphonuclear leucocyte function. $\mathrm{Br} \mathrm{J}$ Anaesth 1995; 74: 315-318. https://doi. org/10.1093/bja/74.3.315.

34. Huettemann E, Jung A, Vogelsang $H$, Hout Nv, Sakka SG. Effects of propofol vs methohexital on neutrophil function and immune status in critically ill patients. J Anesth 2006; 20: 86-91.

35. Skoutelis A, Lianou P, Papageorgiou E, Kokkinis K, Alexopoulos K, Bassaris $\mathrm{H}$. Effects of propofol and thiopentone on polymorphonuclear leukocyte functions in vitro. Acta Anaesthesiol Seand 1994; 38: 858-862. https: //doi.org/ 10.1111/j.1399. 6576.1994.tb04018.x.

36. Yu G, Dymond M, Yuan L, Chaturvedi LS, Shiratsuchi H, Durairaj S, Marsh HM, Basson MD. Propofol's effects on phagocytosis, proliferation, nitrate production, and cytokine secretion in pressure-stimulated microglial cells. Surgery 2011; 150: 887-896. doi: 10.1016/j.surg.2011.04.002.

37. Chang Y, Chen TL, Sheu JR, Chen RM. Suppressive effects of ketamine on macrophage functions. Toxicol Appl Pharmacol 2005; 204: 27-35. doi:10.1016/j.taap. 2004.08.011.

38. Krumholz W, Endrass J, Knecht J, Hempelmann G. The effects of midazolam, 
droperidol, fentanyl, and alfentanil on phagocytosis and killing of bacteria by polymorphonuclear leukocytes in vitro. Acta Anaesthesiol Scand 1995; 39: 624-627. https://doi.org/10.1111/j.1399-6576.1995. tb04138.x.

39. Toyota S, Moriyama M, Otake T, Kono J, Shudou Y, Satake T, Seki K, Masuda S, Amaki Y. Effect of anaesthetic agents on the phagocytic function of human polymorphonuclear leukocytes through analysis with a phagocytic plaque method. Inflamm Res 1995; 44: 204-206.

40. Nishina K, Akamatsu H, Mikawa K, Shiga M, Maekawa N, Obara H, Niwa Y. The inhibitory effects of thiopental, midazolam, and ketamine on human neutrophil functions. Anesth Analg 1998; 86: 159-165. doi: 10.1213/00000539-199801000-00032.

41. Krumbolz W, Endrass J, Hempelmann G. Inhibition of phagocytosis and killing of bacteria by anaesthetic agents in vitro. Br J Anaesth 1995; 75: 66-70. https://doi. org/10.1093/bja/75.1.66.

42. Weiss M, Buhl R, Mirow N, Birkhahn A, Schneider M, Wernet P. Do barbiturates impair zymosan-induced granulocyte function? J Crit Care 1994; 9: 83-89. https:// doi.org/10.1016/0883-9441(94)90018-3.

43. Ploppa A, Kiefer RT, Nohé B, Haeberle HA, Dieterich HJ, Unertl KE, Durieux ME, Krueger WA. Monocyte phaǵocytosis of viable Staphylococcus aureus is impaired by barbiturates, but not by propofol. Infection 2008; 36: 220-225. doi: 10.1007/s15010007-7240-3.

44. Nishina K, Akamatsu H, Mikawa K, Shiga M, Maekawa N, Obara H, Niwa Y. The effects of clonidine and dexmedetomidine on human neutrophil functions. Anesth Analg 1999; 88: 452-458. doi: 10.1213/00000539. 199902000-00042.

45. Chen SL, Zhou W, Hua FZ, Chen Y, Zheng XL, Long XF, Lu J. In vitro effect of dexmedetomidine on the respiratory burst of neutrophils. Genet Mol Res 2016; 15: 1-9. doi: $10.4238 / \mathrm{gmr} .15028069$.

46. Wang Q, Wei H, Fan Z, Lu Y. Effect of norfloxacin and clonidine on human trabecular meshwork cells in vitro. Graefes Arch Clin Exp Ophthalmol 1994; 232: 566-571.
47. Ploppa A, Kiefer RT, Nohé B, Haeberle HA, Dieterich HJ, Unertl KE, Krueger WA. Dosedependent influence of barbiturates but not of propofol on human leukocyte phagocytosisof viable Staphylococcus aureus. Crit Care Med 2006; 34: 478-483. doi:10.1097/01. CCM.0000199067.71968.6E.

48. Marino F, Cattaneo S, Cosentino M, Rasini E, Di Grazia L, Fietta AM, Lecchini S, Frigo G. Diazepam stimulates migration and phagocytosis of human neutrophils: possible contribution of peripheral-type benzodiazepine receptors and intracellular calcium. Pharmacology. 2001; 63: 42-49. doi: 10.1159/000056111.

49. Covelli V, Munno I, Decandia P, Altamura M, Cannuscio B, Maffione AB, Jirillo E. Effects of benzodiazepines on the immune system. Acta Neurol (Napoli) 1991; 13: 418-423.

50. Covelli V, Maffione AB, Greco B, Cannuscio B, Calvello R, Jirillo E. In vivo effects of alprazolam and lorazepam on the immune response in patients with miǵraine without aura. Immunopharmacol Immunotoxicol 1993; 15: 415-428. doi:10.3109/08923979309035237.

51. Traykov T, Hadjimitova V, Goliysky P, Ribarov $\mathbf{S}$. Effect of phenothiazines on activated macrophage-induced luminol-dependent chemiluminescence. Gen Physiol Biophys 1997; 16: 3-14.

52. Trush MA, Van Dyke K. Effect of promethazine on human polymorphonuclear chemiluminescence. Pharmacology 1978;16: 314-320. doi:10.1159/000136787.

53. DeChatelet LR, Qualliotine-Mann D, Caldwell R, McCall CE, Gusdon JP. Effects of promethazine-hydrochloride on human polymorphonuclear leukocytes. Infect Immun 1973; 7 : 403-408.

54. Ordway D, Viveiros M, Leandro C, Jorge Arroz M, Molnar J, Kristiansen JE, Amaral L. Chlorpromazine has intracellular killing activity against phagocytosed Staphylococcus aureus at clinical concentrations. J Infect Chemother 2002; 8: 227-231. doi: 10.1007/s10156-002-0188-4.

55. Menzebach A, Hirsch J, Nöst R, Mogk M, Hempelmann G, Welters ID. Morphine inhibits complement receptor expression, phagocytosis and oxidative burst by a nitric

Vol. 61(1): 60 - 72, 2020 
oxide dependent mechanism. Anasthesiol Intensivmed Notfallmed Schmerzther 2004; 39: 204-211. doi: 10.1055/s-2004-814389.

56. Yeager MP, Procopio MA, DeLeo JA, Arruda JL, Hildebrandt $\mathrm{L}$, Howell AL. Intravenous fentanyl increases natural killer cell cytotoxicity and circulating CD16(+) lymphocytes in humans. Anesth Analg 2002; 94: 94-99. doi: 10.1213/00000539. 200201000-00018.

57. Welters ID, Menzebach A, Goumon Y, Langefeld TW, Teschemacher H, Hempelmann G, Stefano GB. Morphine suppresses complement receptor expression, phagocytosis, and respiratory burst in neutrophils by a nitric oxide and $\mathrm{mu}(3)$ opiate receptor-dependent mechanism. J Neuroimmunol 2000; 111:139-145. https://doi. org/10.1016/S0165-5728(00)00401-x.

58. Perttilä J, Lehtonen OP, Salo M, Tertti R. Effects of coronary bypass surgery under high-dose fentanyl anaesthesia on granulocyte chemiluminescence. $\mathrm{Br} J$ Anaesth 1986; 58:1027-1030. https://doi. org/10.1093/bja/58.9.1027.

59. Jinnouchi A, Aida Y, Nozoe K, Maeda K, Pabst MJ. Local anesthetics inhibit priming of neutrophils by lipopolysaccharide for enhanced release of superoxide: suppression of cytochrome b558 expression by disparate mechanisms. J Leukoc Biol 2005; 78: 13561365. doi:10.1189/jlb.0305169.

60. Welters ID, Menzebach A, Langefeld TW, Menzebach M, Hempelmann G. Inhibitory effects of S-(-) and R-(+) bupivacaine on neutrophil function. Acta Anaesthesiol Scand 2001; 45:570-575. https://doi.org/10.1034/j.1399-6576. 2001.045005570.x.

61. Mikawa K, Akamarsu H, Nishina K, Shiga M, Obara H, Niwa Y. Effects of ropivacaine on human neutrophil function: comparison with bupivacaine and lidocaine. Eur J Anaesthesiol 2003; 20: 104-110.

62. Kawasaki C, Kawasaki T, Ogata M, Sata T, Chaudry IH. Lidocaine enhances apoptosis and suppresses mitochondrial functions of human neutrophil in vitro. J Trauma 2010; 68: 401-408. doi: 10.1097/ TA.0b013e3181af6e56.

63. Azuma Y, Ohura K. Immunological modulation by lidocaine-epinephrine and prilo- caine-felypressin on the functions related to natural immunity in neutrophils and macrophages. Curr Drug Targets Immune Endocr Metabol Disord 2004; 4: 29-36.

64. Jurjus AR, Jarrush-Saadeh D, Nassar C. Modulation of some human mononuclear cells activities by procaine. Middle East J Anaesthesiol 1988; 9: 417-428.

65. Heine $\mathbf{J}$, Jaeger $\mathbf{K}$, Weingaertner $\mathbf{N}$, Scheinichen D, Marx G, Piepenbrock S. Effects of different preparations of propofol, diazepam, and etomidate on human neutrophils in vitro. Acta Anaesthesiol Scand 2001; 45: 213-220. https://doi. org/10.1034/j.1399-6576.2001.450213.x.

66. Schneemilch CE, Bank U. Release of proand anti-inflammatory cytokines during different anesthesia procedures. Anaesthesiol Reanim 2001; 26: 4-10.

67. Sanders RD, Hussell T, Maze M. Sedation and immunomodulation. Crit Care Clin 2009; 25: 551-570. doi: 10.1016/j. ccc.2009.05.001.

68. Odunayo A, Dodam JR, Kerl ME, DeClue AE. Immunomodulatory effects of opioids. J Vet Emerg Crit Care 2010; 20: 376-385. doi: 10.1111/j.1476-4431.2010.00561.x.

69. Mao L, Lin S, Lin J. The effects of anesthetics on tumor progression. Int J Physiol Pathophysiol Pharmacol 2013; 5: 1-10.

70. Liu S, Carpenter RL, Neal JM. Epidural anesthesia and analgesia. Their role in postoperative outcome. Anesthesiology 1995; 82: 1474-1506.

71. Tuman KJ, McCarthy RJ, March RJ, DeLaria GA, Patel RV, Ikankovich AD. Effects of epidural anesthesia and analgesia on coaǵulation and outcome after mayor vascular surgery. Anesth Analg 1991; 73: 696-704.

72. Moding $\mathbf{J}$. The role of lumbar epidural anesthesia as antithrombotic prophylaxis and total hip replacement. Acta Chirurgical Scand 1985; 151: 589-594.

73. Capdevila X, Barthelet Y, Biboulet P, Ryckwaert Y, Rubenovitch J, d'Athis F. Effects of perioperative analgesic technique on the surgical outcome and duration of rehabilitation after major knee surgery. Anesthesiology, 1999; 91: 8-15.

74. Horlocker TT, Wedel DJ. Complicaciones infecciosas de la anestesia regional. Best Pract Res Clin Anaesthesiol. 2008; 22 (3): 451-75. 